\title{
Use of Service-Wide-Vote (Contingency Budget) for National Development: Evidence from Federal Ministries, Departments And Agencies in Nigeria
}

\author{
William Smart Inyang* $^{*} \quad$ Sunday A. Effiong Charles Effiong John Ogenyi Oboh \\ Department of Accounting, University of Calabar, P.M.B. 1115, Calabar, Cross River State, Nigeria
}

\begin{abstract}
This paper examines the use of service-wide-vote (Nigeria's contingency budget) for national development. Documentary pieces of evidence have shown that the Federal government of Nigeria through its MDAs has grossly short-changed Nigerians through the year-in-year-out mismanagement of the service-wide-vote. The objective of this study is therefore, to evaluate the extent to which Federal MDAs in Nigeria have been able to use the servicewide-vote to achieve national developmental objectives. To what extent has the service-wide-vote been used to develop the Nigerian Nation? In order to provide an answer to the foregoing question, primary sources, scholarly journals and reputable online and library sources were used to obtain research materials. The study revealed that federal MDAs and even the EFCC abused the service-wide-vote to the tune of over $\$ 4.17$ trillion between 2004 and 2018 due to non-compliance with rules governing the use of the vote and this made it difficult for the national developmental objectives of the vote to be achieved. The following recommendations were therefore, suggested by the paper: allocation of 5 percent of the annual budget to service-wide-vote, regular replenishment of releases from the service-wide-vote, obtaining approval from the National Assembly before releasing funds from the vote, roll over of unspent funds, prosecution of corrupt MDA officials and avoiding those sharp practices that will make the use of the service-wide-vote ineffective in achieving national developmental objectives.
\end{abstract}

Keywords: Federal MDAs, National Development and Service-wide-vote

DOI: $10.7176 /$ RJFA/10-10-06

Publication date:May $31^{\text {st }} 2019$

\section{Background of the Study}

The Chairman, Senate Committee on Anti-Corruption, Chukwuka Utazi recently accused the Economic and Financial Crimes' Commission (EFCC) boss, Ibrahim Magu of illegally spending an additional sum of 1.8 billion from the Service Wide Vote and he responded and said: "You are right. Things should be done properly." (ThisDaylive, February 21, 2017)

Public expenditure management literatures have recently been bombarded with budget-related frauds. Globally, budget-related frauds alone constitute a large percentage of the 18.7 percent of the frauds committed by government entities (Association of Certified Fraud Examiners Reports of January, 2014 and October, 2015 as cited in Hofmann, 2016). Federal Government fraud alone, according to ACFE as cited in Hofmann, is higher than the frauds committed by both local and state governments. Budgets which are known globally as useful tools for achieving national development, have therefore, been severally abused by federal entities. In Nigeria, the abuse of budgets has become a recurring phenomenon which has defiled financial regulations, budgetary and constitutional provisions. Ekott (2012) quoted a former Speaker of the Nigeria House of Reps, Aminu Waziri Tambuwal as follows:

"Nigeria has a long history of abuse budgets. For years, hardly has any subject pitched the Executive against the National Assembly as the budget. The entire exercise has so ridiculed the budget system turning it to mere ritual and that the Appropriation Act is observed more in breach than execution."

Frivolity and impulsiveness according to Olufemi (2016), had characterized government spending since the return of Nigeria to democracy in 1999. Budget abuse in Nigeria is further worsened by the fraudulent use of the service-wide-vote (a component of the annual budget meant for emergencies and contingencies). The service wide vote is a contingency budget which is operated under Section 83 (1) and (2) of the 1999 constitution of Nigeria. The vote usually constitutes 5 percent of the annual budget and it is statutory used to pay for items not included in the annual budget. No money should be released from the vote without legislative approval. Furthermore, expenditures from the vote must be immediately replenished through supplementary estimates and appropriation bills.

Various reports of committees of the Nigeria's national assembly revealed that between 2004 and 2018, the service-wide-vote (contingency budget) has been abused to the tune of over $\$ 4.17$ trillion. A segment of the 2013 report of House of Reps Committee on Public Accounts reads:

"contrary to the foregoing (i.e. using the vote for emergencies), after its examination of the Auditor-General's Reports on the accounts of MDAs, the Committee discovered indiscriminate use of the vote in funding government projects and programmes that should otherwise have been provided for in the annual budget, as such expenditures 
were never contingent in nature" (Cooljoe, 2013).

However, even though studies carried out by Omopariola and nine others between 2002 and 2016 have reported an increase in budget abuse, very little research has been reported on the effective use of the servicewide-vote in fostering national development. The purpose of this paper is therefore, to evaluate the extent to which Federal MDAs have used the service-wide-vote for the development of Nigeria. To what extent have federal MDAs in Nigeria used the service-wide-vote for national developmental purposes? The argument of this paper is that federal MDAs in Nigeria have not effectively used the service-wide-vote for national developmental purposes due to lawless practices. The foregoing argument is important because the pieces of evidence that will be used in proving its validity can encourage compliance with regulatory procedures, budgetary and constitutional provisions and can even foster the effective use of the service-wide-vote for the development of Nigeria as a nation.

\subsection{Operational definition of key variables}

1.1.1 Use of Service Wide Vote: This is the sum of the response scores of each respondent's perception of how the service wide vote should be used to achieve national development in Nigeria. (please see table 3 on page 21). 1.1.2 National Development: This is the sum of the response scores of each respondent's perception of the effect of the correct use of the service wide vote (please see table 4 on page 22).

\section{Theoretical framework}

The relationship between use of service wide vote and national development is supported by the following theories: fraud triangle theory (why people commit fraud), fraud diamond theory (pressure, opportunity and rationalization can only lead to fraud when the fourth element called 'capability' is present), agency, stewardship and accountability theories (statutory responsibility of agents to their principals, for example, how responsible and committed is the federal government of Nigeria to their principals i.e. Nigerians?), time value of money concept (funding should not be delayed due to the changing value of money) and contingency theory (allowing changing circumstances to dictate what should be done is a more rewarding approach for any successful budget implementation).

\section{Empirical Review of Literature}

The empirical review of literature will include only those studies that follow all the time-tested theories listed under the theoretical framework of this study. Therefore, the following theories i.e. fraud triangle, fraud diamond, agency, stewardship, accountability, time value of money and contingency are used by the researchers to argue that the pursuance of self-interest by custodians of public resources will lead to lawless practices, delay in funding and will also prevent such custodians from allowing changing circumstances to dictate what should be done. Ten (10) empirical studies on budget abuse that follow these theories have found general support for the argument that the pursuance of self-interest often leads to lawless practices, delay in funding and disregard for changing circumstances during the planning process (Olatunji 2015; Olurankinse 2012, 2013; Olurankinse, Yabugbe, and Ibadin 2008; Omitoogun and Oduntan 2006; Omopariola 2002; Onyiah, Ezeamama, Ugwu, and Mgbodile 2016; Renzio and Smith 2005; Ugoh and Ukpere 2009; Usman and Jimoh 2013).

Strengthening of the public budget has long been recognized worldwide as the one and only instrument of economic development. Abandoning this important instrument has consequently become detrimental to the economic development of both developed and developing countries. Premchand (2007) believed that public budgeting relates majorly to economic growth, employment generation and income redistribution that is more favourable to the economy. Premchand asserted that budgeting for economic developmental purposes cannot be achieved without an organized planning. Budgeting according to the author, has passed through many phases such that in 1985 almost 300 plans were prepared by developing countries. Premchand also revealed that industrialized countries of the west considered some aspects of organized planning in their budgeting systems. It was not until the early 1990s that the formulation of economic development plans was unfortunately abandoned by several countries especially the soviet bloc, the author further asserted. Premchand concluded that a revival has however, taken place in these countries as they now strongly believe that the one and only instrument of economic development is the strengthening of public budget. This study has shown that organized planning enables public budgeting to contribute effectively towards economic development and this information will guide public sector organizations that use budgets for national developmental purposes. It has been empirically established that economic development can be achieved when organized planning begins with a major economic development subsector like education.

Edame (2015) believed that education should not be planned casually since the economic, social and political development of any country depended majorly on it. Education according to Edame becomes more cost-effective, rewarding and simple to implement when it is carefully planned. The author asserted that mistakes caused by lack of planning are usually costly and the limited natural and human resources of developing countries could not therefore, be wasted. Edame further asserted that the factors which influenced the planning of the education of a 
developing country are as follows: the number of people who demand for the education, level of manpower required, socio-economic and cultural changes, level of communication required, the growth in population in relation to the available educational opportunities and those aspects of a country's development that require the most attention first and other considerations that border on environment and ecology. This study is important because it emphasizes effective planning in the educational sub-sector which all aspects of national development depend on. It also emphasizes that factors which influence whatever that is being planned for should also be identified. The absence of an effective planning is therefore, responsible for the failure of budgets in Nigeria. Two recent studies carried out in Nigeria showed how Nigeria failed to strengthen its budgets of 2012 to 2014 thus suggesting that the organized planning advocated by Premchand in 2007 was not used. This also clearly suggests that when organized planning is jettison, budget is bound to fail.

Ehigiamusoe and Lean (2016) examined how the national budget of Nigeria was implemented by focussing on the budgets of 2012 to 2014. In order to achieve the study objective, the actual budget performances were compared with their projected figures using economic development indices such as rate of inflation, rate of exchange, real GDP growth rate and production of crude oil. The results of the foregoing comparisons were poor budget performances. During the period under review, revenue and expenditure components of the budgets failed to meet their targets respectively. The authors also discovered that actual expenditure in aggregate terms was very low while capital budget was poorly implemented. Ehigiamusoe and Lean's study was supported by the study conducted by Edeme and Nkalu (2017) who used the descriptive research design to examine whether Nigeria's 2013 capital budget performance was in conformity with the country's transformation agenda. Edeme and Nkalu revealed that the level of implementation of Nigeria's capital budget was not adequate to achieve the desired economic development objectives. They attributed this inadequate capital budget performance to failure and delay in the release of budgeted funds and the failure to monitor the performance of the budget. Further studies have also been conducted to explain why economic development plans have failed to achieved their desired objectives.

Ojo (2012) focused on carrying out a detailed analysis of factors that have made development plans not to achieve their set goals. The author revealed that despite the enormous human and natural resources that abide in Nigeria, majority of the plans are over-ambitious and unrealisable. A second hindrance according to Ojo is a weak database. The author further attributed the failure of national development plans to the following factors: political constraints, managerial ineffectiveness, lack of budget discipline and deliberate corruption. This study has identified impediments to the effective implementation of national development plans. Ojo has therefore, been able to show that the success of any national development plan majorly depends on the avoidance of acts that violate budgetary principles. Ojo's study is supported by Egbo, Nwakoby, Onwumere and Uche (2010) who investigated the origin and use of security votes in Nigeria. The authors argued that security votes have since independence become conduit pipes for stealing money from the nation's treasury. They also argued that the structure of government in Nigeria is what has led to the wanton abuse of the votes by all the tiers of government in Nigeria. According to the authors, the political class in Nigeria lacked the culture of accountability because of autocratic and partially democratic regimes coupled with the fact that Nigeria has emerged as a rentier State that largely depended on oil revenue. They all concluded that the citizens cannot call their rulers to order because of the corruption of those who represent them. This study has provided additional evidence that budgets in Nigeria are not effectively used for the achievement of national development.

Ojo's study is also consistent with the works of Amaechi, Amadi and Nnaji (2018) who asserted that selfcentred elements in the Nigerian Parliament had taken over the approval of the nation's budget estimates in a manner contrary to national interest. According to the authors, several reports disclosed that these legislators had made themselves the highest paid in the world and had collected bribes from ministries during their oversight functions. The authors therefore, used secondary data and content analysis to examine and analyse the effects of these prebendalists' activities and the means used by these prebendalists during the appropriation process in the legislature. The results of the analysis showed the following major effects: unrealistic budget estimates, nonperformance of legislative oversight functions and delay in the passage of budgets. The authors further revealed that some government agencies were used by these corrupt legislators as conduit pipes for receiving illegal allowances, illegally awarding and implementing constituency projects and padding of budgets. This study has again exposed those corrupt practices that are used by legislative and government officials to abuse government budgets that are under their controls. This has also provided another evidence that budgets in Nigeria have not been effectively used to achieve national development.

Another study which provided evidence for the ineffective use of budget for national developmental purposes was that conducted by Olaoye (2014). The author examined the effect of lawless legislative practices on budget process in Nigeria. These lawless legislative practices according to Olaoye were as follows: disagreement over what the appropriate oil bench-mark should be despite the provision in the 2007 Fiscal Responsibility Act that oil bench mark should not be changed, illegal insertion of non-constituency projects into the budgets by members of the Nigerian legislature, members of the legislature collecting bribes for the easy passage of government agencies' budgets and use of the appropriation process to witch-hunt perceived political opponents. This author further 
revealed that the adverse effects of these lawless practices were late passage of the national budget, arguments over unimportant details relating to legislative oversight functions, unnecessary disagreements between the executive and the legislature and inconsistencies in the budget policy framework which had all impacted negatively on the Nigerian economy. In furtherance of the discussion on lawless practices, budget padding (a lawless legislative practice) which Amaechi, Amadi and Nnaji reported in 2018, was separately investigated by Theophilus and Perpetua (2016). Theophilus and Perpetua used content analysis, Journals and related articles to examine budget padding in Nigeria. The authors revealed that budget padding in Nigeria's budgeting and finance process had been in existence for many years until it reached an alarming rate in 2016. According to facts obtained by the authors from reviewed articles, the sum of $\$ 100$ billion was padded illegally in 2016 and this made the budget of that year to be inflated to $\$ 6.06$ trillion. Inflating the 2016 budget by $\$ 100$ billion made the budget unrealistic and abusive since it provided the conduit pipe for corrupt government officials to siphon public funds for their personal uses.

As an extension of the study conducted by Theophilus and Perpetua on budget padding, another study was carried out by Chiamogu and Chiamogu (2017) to establish whether the padding of budget was legal or not. The authors used secondary data extensively to examine the functions of the legislative arm of government in the appropriation process in order to determine whether it has the power to change or make additional budgetary provisions. The authors also revealed that while the national economy is managed by the executive, the legislature uses its power of appropriation to authorize expenditures from the consolidated revenue fund to achieve effective governance in Nigeria. This study concluded that budget padding is legal to the extent that it is done at the national interest. This study is important because it has shown that budget can be legally padded to achieve effective governance in Nigeria. Therefore, budget padding is illegal only when it is done for personal development other than national development. This information will no doubt serve as a guide for budget controllers in Nigeria. None of the studies reviewed so far has specifically attempted to investigate the extent to which the service wide vote (a proportion of the national budget called a contingency budget) is used for the development of the Nigerian nation despite the fact that it has been severally abused by federal ministries, department and agencies on frequent bases. The abuse of the service wide vote is currently going on in Nigeria on a large scale and it unfortunately perpetuated by both the so called regulators and the regulated. The current study will therefore, attempt to fill this gap.

\section{Methodology}

The current study has a target population of 60 made up of all the senior staff of the offices of the Auditor-Generals of the State and Local governments, House of Assembly and State Planning Commission all in Cross River State, Nigeria. From this target population, 44 members were accessible and a sample of 40 members was drawn from this small population. This sample size was determined using Yaro Yamani formula as follows:

$$
n=\frac{N}{1+N(e)^{2}}
$$

Where $\mathrm{n}=$ sample size, $\mathrm{N}=$ the accessible population and $\mathrm{e}=$ level of significance. After substituting the appropriate values into the above formula, the sample size was obtained as follows:

$$
\begin{gathered}
n=\frac{44}{1+44(0.05)^{2}} \\
=\mathrm{n}\left(1+44(0.05)^{2}\right)=44 \\
=\mathrm{n}(1+0.11)=44 \\
=\mathrm{n}(1.11)=44 \\
=1.11 \mathrm{n}=44 \\
\mathrm{n}=\frac{44}{1.11}=39.63963964=40 \text { approx. }
\end{gathered}
$$

Ex-post facto research design approach was adopted because of the inability of the researcher to manipulate the independent variables. It is worthy of mention that the independent variable (i.e use of service wide vote) generated by the study, had already influenced the dependent variable before the researcher commenced the research. What the study investigated was therefore, the nature of the effect of this independent variable. A random sampling technique was used to select a sample of 40 members from the accessible population. A 5-point likert scale structured questionnaire containing eleven (11) statements or items, were given to all the sample members (please see table 1 on page 10). 34 sample members responded and returned their questionnaires while 6 of them failed to return their questionnaires.

Cronbach alpha was used to test the reliability of the 5-point likert scale ordinal data in order to facilitate their conversion to interval data. This approach was adopted in order to facilitate the application of simple linear regression analysis technique. The following equation was therefore, used to express the relationship between the dependent and independent variables:

$N D E V=f(U S W V)$

The simple linear regression model now becomes: 


$\begin{array}{ll}\text { where, } & \\ \text { NDEV } & = \\ \text { USWV } & = \\ b_{0} & = \\ b_{1} & = \\ e_{i} & = \\ b_{0}, b_{1}, & \geq 0\end{array}$

$$
N D E V=b_{0}+b_{1} U S W V+e_{i}
$$

Please see table 7 on page 16 showing the distribution of total likert scores of USWV and NDEV used in running the simple linear regression.

\section{Results from Primary Research}

\subsection{Analysis of Respondents by Ministries, Departments and Agencies (MDAs)}

Table 2 on page 11 shows the MDAs and cadres of sample members. The 34 respondents were categorized as follows: 12 of the respondents were senior audit staff of the office of the Auditor-General for Cross River State representing $35 \%$ of the total respondents. Another 8 senior audit staff representing $24 \%$ of the total respondents came from the office of the Auditor-General for local governments. 8 legislators representing $24 \%$ of the total respondents came from the Cross State House of Assembly while 6 budget control officers representing 18\% of the total respondents came from the Cross River State Planning Commission. In all, 20 auditors participated in the survey and this represented $59 \%$ of the total respondents. Auditors therefore, participated in the survey more than legislators and budget control officers who constituted the remaining $32 \%$ of the total respondents. However, all the participants were financial regulators. All the respondents were therefore, knowledgeable in the research area. What necessitated the dominance of audit staff was the need to collect the appropriate information for the study and to properly address the budget-related fraud nature of the problem.

\subsection{Test of Reliability and Validity of primary data prior to data analysis}

The primary data collected in respect of predictor variable (use of service wide vote) and the criterion variable (national development) all satisfied the Cronbach's alpha reliability coefficient of 0.70 and above. The reliability coefficients for the predictor and criterion variables were 0.70 and 0.76 respectively (see tables 5 and 6 on pages 14 and 15 respectively. The validity of the data collected in respect of use of service wide vote and national development was verified and proved using linearity and normality tests. The data satisfied both the linearity and normality assumptions as indicated on the simple scatter plot (figure 1) and histograms (figures 2 and 3 ) all on pages 18 and 19 .

\subsection{Regression analysis (see table 8 on page 17)}

The contribution of the predictor variable i.e. use of service wide vote was extremely low and the linear relationship between the variables was not significant $\left(\mathrm{R}^{2}=.073, \mathrm{~F}(1,32)=2.530\right.$, n.s). The intercept or constant (i.e. expected value) of the criterion variable (i.e. national development) was positive when the predictor variable equals to zero and this was also not significant $\left(\beta_{0}=.611, n . s\right)$.

\subsection{Hypotheses testing(see regression output table 8 on page 17)}

The results derived from testing the null hypothesis are as follows:

Hypothesis: There is no significant relationship between use of service wide vote and national development in Nigeria. The results of the regression indicated a weak positive correlation coefficient and it was not $\operatorname{significant}\left(\beta_{1}=.31, n . s\right)$. The null hypothesis was therefore, accepted while the alternative hypothesis was rejected.

\section{Results from Secondary Research}

$>$ The Nigerian National Assembly recently approved a virement of $\$ 143.5$ billion from a service wide vote of $\$ 943.5$ billion meant for 1,403 projects. (Opalana, 2018)

$>$ Pensions Transitional Arrangement Department (PTAD) could not account for $\$ 24$ billion taken from 2010 service wide vote. (African Orbit, 2014)

$>$ Some federal agencies could not account for over $\$ 114$ billion received from the service wide vote between 2004 and 2012. (The Citizen Online, 2014)

$>$ Federal Ministry of Information failed to account for $\$ 6.5$ billion it received from the service wide vote between 2004 and 2009 while Office of the Secretary to the Government of the Federation could not account for $\$ 4$ billion it received from the service wide vote between 2004 and 2012. (Majekodumi, 2013) 
$>\quad 22$ federal MDAs received $\$ 21.1$ billion from the service wide vote to execute capital projects between 2003 and 2006. (Odunaro, 2013)

$>$ Federal Government of Nigeria spent a service wide vote amount of $\$ 4.17$ trillion instead of $\$ 1.8$ trillion on recurrent expenditure items between 2004 and 2012. (Cooljoe, 2013 and Ovuakporie, 2013)

$>$ Between 2015 and 2017, Military Pensions Board spent over $\$ 44$ billion from the service wide vote without legislative approval. (Bona, 2018)

$>$ Economic and Financial Crimes Commission spent $\$ 1.8$ billion in 2016 without obtaining approval from the National Assembly. (ElombahNews, 2017 and Ogunmade, 2017)

$>\quad$ The reasons for releasing $\$ 257$ billion and $\$ 157$ billion from the service wide vote consecutively for two years to the Office of the Accountant-General of the Nigerian Federation, could not be revealed while the amount released from the service wide vote in 2013 was 40 percent. (Oluwasegun and Anofi, 2013)

$>$ The service wide vote constituted more than $5 \%$ of the annual budget.

$>$ The Federal Government's $\$ 1.5$ trillion National Social Investment Programme (NSIP), a service wide vote has failed (The Nigerian Senate as cited in Bona, 2018)

$>$ The vote is not regularly replenished as statutorily required by law.

$>$ The vote is seen as an easy source of money for corrupt civil servants.

$>$ The excess money from the vote is shared at year end.

$>$ Most MDA officials erroneously believe that the service wide vote is not meant for only unforeseen expenditures since it is service-wide and not agency-specific.

$>$ The use of the service wide vote for personal development by corrupt MDA officials is seen as a norm in Nigeria.

$>$ Majority of the federal MDAs do not know when to use the service wide vote.

$>$ Loans are granted from the vote to MDAs who did not planned and manage their annual budget well.

The pieces of evidence provided by the above secondary data support the results revealed by the primary research, indicating again that there is no significant relationship between use of service wide vote and national development.

\section{Discussion}

The variability of the criterion variable (national development) as explained by the predictor variable (use of service wide vote) is indicated by an adjusted R square of .044 or approximately .04 (please see table 8 on page 17). The model was indeed not significant since it has an F- statistic of 2.530 at the alpha level of .12(i.e. .122). Therefore, the model has a very low explanatory power. The analysis of the hypothesis will be based on the regression output indicated on table 8 .

\subsection{Hypothesis: (please see table 8 on page 17)}

There is no significant relationship between use of service wide vote and national development. $\left(\beta_{1}=.31, n\right.$.s $)$. What this means for the unstandardized coefficient of . 310 is that if the use of service wide vote increases by $¥ 1$, national development in Nigeria will increase by only $\$ 0.310$, provided all other variables are held constant. For a standardized coefficient of 0.271 , it means that as use of service wide vote increases by 1 standard deviation, national development in Nigeria will increase by 0.271 standard deviation provided all other variables are held constant. This positive relationship was however, not significant (i.e. not being true) at a t-test statistic of 1.591 based on the alpha level of .05 (i.e. .122). The positive relationship that would have existed between use of service wide vote and national development is very weak and not significant mostly due to the wanton abuse of the service wide vote by government MDAs in Nigeria.

The Legislature and the Executive arms of government failed to comply with budgetary and constitutional provisions. National Assembly illegally approved the release of funds from SWV, (a contingency vote) to service 2019 election. 2019 election is not an unforeseen expenditure item. The service wide vote is meant for unforeseen expenditures on a service wide basis i.e. variety of expenditures which are unforeseen and unpredictable and which relate to 1,403 government projects. The expenditures for which this virement was required were usually not contingent in nature. Since the use of the savings of one expenditure subhead to offset the over expenditures on another does not call for immediate replacement, any amounts taken from the service wide vote as virements are therefore, oftentimes not replaced. This is contrary to section 83 (2) of the 1999 constitution of Nigeria which stipulates that any amount taken from the service wide vote should be replaced as soon as possible through supplementary estimates and appropriation bill. This item of expenditure ought to have been provided for in the 2018 annual budget and the National Assembly granting approval for a virement of 143 billion for 2019 election (predictable expenditure) from a special fund meant for 1,403 projects, was wrong. This is a misappropriation of the service wide vote. Money meant for national developmental projects will be adversely affected and this can lead to project delays. Service wide vote is constitutionally meant for expenditure items that cannot be found in the regular budget. The supreme audit institution will accordingly query this transaction and will cause the right 
thing to be done.

Poor financial accountability made the federal government through its MDAs, not to be able to account for a whooping sum of almost $\$ 4.9$ trillion between 2004 and 2018. What this means is that about $\$ 5$ trillion will not be available for the provision of infrastructures, education, health care services, economic stability and growth, direct production of goods and services, establishment and management of public enterprises and industries for social welfare and employment generation, poverty reduction, and reduction of income inequality and regional disparity and disaster situations in the country. This discovery can encourage regular audit and oversight functions, sanctions and improved financial accountability.

The service wide vote is established to provide emergency funds for government to promote economic growth and economic stability in Nigeria. The failure of government programmes due to the abuse of the service wide vote means that social welfare promotion and provision of public goods and services which government aims to achieve, will not be attained.

Not replenishing releases from the service wide vote as soon as possible as statutorily required by section 83 (2) of the 1999 constitution also means that funds will not be available for Nigeria to tackle emergencies, disaster situations and excessive borrowings.

The use of service wide vote for recurrent expenditures has turned the vote into a parallel budget and this has provided a conduit pipe for corrupt MDA officials to steal huge sums of money from the national treasury. Looting the country's treasury in style will further widened the income gap between the poor and the rich and government will fail in achieving equality in income and wealth distribution and will also lead to regional disparity in Nigeria.

Failure of government programmes, failure to regularly replenish SWV, using SWV as easy source of money, sharing of excess SWV at year end, treating the SWV as a general fund, using SWV for personal development, not knowing when to use SWV and using SWV to grant loans to MDAs are some of the reasons why the SWV cannot be effectively used for national developmental purposes. This discovery will also make financial regulators to become proactive in their approach and further tightened their financial controls and recommend stiffer penalties.

The erroneous believe that the service wide vote is not meant for only unforeseen expenditures has caused MDAs officials to circumvent legislative authority and constitutional provisions. The abuse of the service wide vote has dented the image of Nigeria globally and it has been discovered to be one of the reasons why Nigeria is in recession today and this emergency fund has produced emergency billionaires instead of improving national development. Even EFCC that is established to regulate the MDAs has also abused the service wide vote and this has made it not credible enough to regulate the use of the service wide vote. In summary, the results revealed noncompliance with budgetary and constitutional provisions and poor financial accountability. This consequently gave rise to the abuse of the service wide vote which in turn made it difficult for the national developmental objectives to be achieved.

\section{Contribution To Knowledge}

In addition to the few researches that have shown how security votes are used to steal public funds in Nigeria, this research has disclosed another device used by MDAs in Nigeria to steal from the nation's treasury on a larger scale. This time around, the focus is on a service wide vote that is purported to cover many services classified as emergencies and contingencies. The current study suggests that the fraud triangle is becoming larger and more complex to break because of 'use of service wide vote', another conduit pipe for stealing public funds. This study has therefore, shown that budget-related frauds are now committed on a larger scale through the use of a government contingency budget tagged 'the service wide vote'. The larger the vote, the larger the fraud.

\section{Conclusion}

National development has to do with reducing inequalities in income and wealth distribution. Unfortunately, federal MDA officials in Nigeria rather prefer to use service wide vote for their personal development. The use of the service wide vote to siphon or steal public fund has further widened the income gap between the poor and the wealthy in the society. Government intends to reduce inequality in income and wealth distribution. This can be done when it reduces the income of the rich and raise the standard of living of the poor. Unfortunately in Nigeria, because of the abuse of service wide votes, this objective has not yet been achieved. While billions and trillions of naira are stolen on a frequent basis, through the wrong use of the service wide vote, the national minimum wage still remains as $\$ 18,000$ i.e. about $\$ 49$.

Making provisions for emergencies, contingencies and unforeseen events will enable government to achieve economic stability that is necessary for national development. The service wide vote can be used to tackle business and other fluctuations or instability in the economy. Unfortunately, this developmental objective has not been achieved. Inflation is still very high, there is fluctuation in oil revenue, Niger Delta crisis and insurgency to mention but, a few.

The service wide vote was established to take care of emergencies and contingencies in all the sectors of the Nigerian economy. There is no area of government programmes or projects where unforeseen problems do not 
occur. Corrupt use of the service wide vote has not enabled the Nigerian government to establish and manage large number of public sector industries for social welfare, employment generation and poverty reduction. Wrong use of the vote has also not enabled government to mobilize sufficient resources for public sector investment and reduce regional disparity. The effective use of service wide vote is therefore, critical to the national development of Nigeria since the occurrence of unforeseen problems is inevitable.

The abuse of the service wide vote is one of the reasons why in Nigeria we now have recession, emergency billionaires, poor national developmental indices, excessive government borrowings, inequality in income and wealth distribution and a dent on Nigeria's image at the global arena. Nevertheless, the service wide vote can be used to reduce government borrowings, boost the capacities of government project contractors, improve national developmental indices, arrest national disaster situations and refund government guaranteed loans. The use of the service wide vote has failed because of the deliberate refusal of MDA officials to comply with laid down financial rules and regulations and because in Nigeria, personal development is more often than not, achieved at the expense of national development.

\section{Recommendations}

* The federal government and other regulatory bodies should ensure that what is set aside at a time as service wide vote does not exceed 5 percent of the national budget.

* Releases from the service wide vote should be replenished as soon as possible as this will enable MDAs to take care of their unexpected expenditures and arrest other emergency or unforeseen situations. Replenishment can be facilitated when MDAs prepare supplementary estimates and forward same to the National Assembly for approval. This is a constitutional requirement.

* MDA officials who spend from the service wide vote without obtaining approval from the National Assembly should be prosecuted and made to refund such unappropriated funds from their personal resources.

* MDAs should prepare their budgets accurately and realistically and should regularly review them so that the service wide vote is not used as a parallel budget. This will also prevent the overspending of the service wide vote.

* Any excess or unspent fund from the vote at year end should not be returned to the treasury but, should be used to arrest the contingencies and emergencies of the subsequent year. The usual practice of using the excess or unspent fund from the current year's SWV to reduce the budget of the following year should be discouraged. The budget size of the subsequent year should be based on prevailing circumstances or situational factors. This will check the mad rush to retire or account for excess fund when the budget is about to expire at year end and will also minimize the fraudulent use of the unspent fund.

* MDA officials who see it as a norm to use the service wide vote to enrich themselves should be appropriately sanctioned.

* MDAs should know exactly when to release fund from the service wide vote. Some unforeseen expenditures are predictable while others are not. Contingencies are unforeseen in terms of their time of occurrence but, we know they will occur i.e. they are predictable in terms of occurrence but, their time of occurrence cannot be determined since their occurrence depends on the occurrence of other events.

* The practice of granting loans to MDAs from the service wide vote should be discouraged since the chances of recovering such loans are usually slim. MDAs ask for loans from SWV because they fail to prepare and manage their annual budgets in an appropriate manner.

\section{Direction for Future Research}

Future research in the area of public expenditure management should attempt to answer the following questions:

* Should the service wide vote be excluded from the annual budget of Nigeria?

* Is there any significant difference between the approved and actual releases from the service wide votes of federal ministries in Nigeria?

* What factors are responsible for the year-in-year-out abuse of the service wide votes of federal ministries in Nigeria?

\section{Acknowledgments}

We are deeply grateful to the senior staff of the offices of the Auditor-General for State and Local Governments, Cross River State House of Assembly and Cross River State Planning Commission for providing useful research materials. Accounting and Finance Research Association (AFRA) is also acknowledged for including some aspects of this work in their proposed 2018 conference proceedings as this provided us with the inspiration to convert the work to a full research paper. 


\section{References}

African Orbit (2014, March 11) We can't account for N24bn received from service wide vote — Police Pension Office. Retrieved from: http://africanorbit.com/news/134/we-cant-account-for-n24bn-received-fromservice-wide-vote-police-pension-office.html

Amaechi, O. C., Amadi, C. O., \& Nnaji, S. E. (2018). Prebendalism and budget authorization in the Nigerian legislature. International Journal of Academic Research in Business and Social Sciences, 8(7), 59- 73. DOI: 10.6007/IJARBSS/v8-i7/4324.

Bona, S. (2018, April 6) Senate decries performance of N1.5 trillion social investment scheme Retrieved from: https://www.today.ng/news/nigeria/senate-decries-performance-5-trillion-social-investment-scheme103319

Bona, S. (2018, May 4) Senate queries Military Pensions Board over N44bn pension funds Retrieved from: https://www.today.ng/news/nigeria/senate-queries-military-pensions-board-n44bn-pension- funds-111054

Chiamogu, A. P., \& Chiamogu, U. P. (2017). Budget Padding and Appropriation in Nigeria: An Appraisal of Legislative Powers in an Evolving Democracy. International Journal of Management, Policy and Administrative Studies, 3(1), 357-375.

Citizen Online (2014, April 8) Service Wide Vote: N114 billion controversial releases - Punch Newspaper. Retrieved from: https://thecitizenng.com/service-wide-vote-n114-billion-controversial-releasespunch/Constitution of the Federal Republic of Nigeria (Promulgation) 1999 No. 24

Cooljoe (2013, December 23). FG spent N4.17tn illegally in nine years-Reps' report- Nigerian Best Forum- NBF. [online] Available at http://www.nigerianbestforum.com/index.php?topic=378598.0;wap

Edame, G. E. (2015). Planning as an instrument for national development in Nigeria. Global Journal of Management and Business Research: B Economics and Commerce, 15(4), 1-7.

Edeme, R. K., \& Nkalu, N. C. (2017). Budgeting for development: Lessons from 2013 capital budget implementation in Nigeria. Journal of Economics and International Finance, 9(4), 30-35. DOI: 10.5897/JEIF2017.0835

Egbo, O., Nwakoby, I., Onwumere, J. \& Uche, C. (2010). Legitimizing corruption in government: Security votes in Nigeria. African Studies Centre Leiden, The Netherlands ASC Working Paper 91

Ekott, I. (2012). Investigation: Ministers violate monetization policy, illegally spend billions on exotic cars. Premium Times. [online] Available athttp://www.premiumtimesng.com/news/103394-investigationministries-violate monetization-policy-...

ElombahNews (2017, February 21) Senate angry with Presidency, EFCC over N1.8 Billion Service Wide Vote release Retrieved from: https://elombah.com/senate-angry-with-presidency-efcc-over-n1-8- billion-servicewide-vote-release/

Frauds \& Scandals (2018, April 22) AGF disclaims extra-budgetary spending over the release of N10bn for contractors' liabilities. Federal Ministry of Finance Release. Retrieved from: http://www.proshareng.com/news/Frauds\& Scandals/AGF-Reacts...

Kizito Uyi Ehigiamusoe, K. U., \& Hooi Hooi Lean, H. H. (2016). Analysis of national budget implementation: Evidence from 2012-2014 budgets of Nigeria. Journal of Applied Economic Sciences 11(2):317-32

Kukava, M. (2016) Spending from contingency funds remains a serious problem. Transparency International, Georgia. Retrieved from: https://www.transparency.ge/en/blog/spending-contingency-funds-remainsserious- problem

Majekodumi, S. (2013, December 16) Reps probe SGF, ministry over N106b Service Wide vote Retrieved from: https://news2.onlinenigeria.com/news/327268-reps-probe-sgf- ministry-over-n106b-service-wide- vote.html

Odunaro, K. (2013, July 1) LOOTING WITH STYLE: Reps, service wide votes and contingencies scam. News Express Retrieved from: http://newsexpressngr.com/news/detail.php?news=2124

Ogunmade, O. (2017, February 21). Senate C'ttee accuses Magu of extra-budgetary spending, abuse of service wide votes. Thisday Newspaper Retrieved from: http://www.thisdaylive.com/index.php/2017/02/21/senatecttee-ac...

Ojo, E. O. (2012). Constraints on budgeting and development plan implementation in Nigeria: An overview. European Journal of Sustainable Development, 1(3), 445-456.

Olaoye, F. O. (2014). An exploratory evaluation of legislative lawlessness in the Nigerian budget process. Singaporean Journal of Business Economics, and Management Studies, 3(2), 1-8.

Olufemi, J. (2016). How 3 Nigerian Presidents wasted N247 billion oil savings, gave illegal loans, to NSA, Sao Tome Premium Times Nigeria. Aonline] Available at http://www.premiumtimesng.com/news/headlines/198822 exclusive-3-nigerian- presidents-wasted- n247billion-oil-savings-gave-illegal-1...

Olurankinse, F. (2012). Due process and budget implementation: An evaluation of Nigerian Public sector auditing: Asian Journal of Finance and Accounting, 4(2), 144-154.doi: 10.5296/ajfa.v4i2.1689

Olurankinse, F., Yabugbe, P. \& Ibadin, L. (2008) Budgeting as a tool for control and Performance evaluation in 
the public sector. Journal of Research in National Development, 6,(2), 1-9. [online] Available at http://www.transcampus.org/JORINDV6Dec2008/JournalsV6NO2Dec20085.html.

Olurankinse, F. (2013). Poor budgetary performance: Causes and implications for development. European Journal of Accounting Auditing and Finance Research. 2(1), 53-66.

Oluwasegun, V., and Anofi, D. (2013, October 24) Reps probe Fed Govt's use of N1. 6 trn Service Wide Vote. The Nation. Retrieved from: http://thenationonlineng.net/reps- probe-fed-govts-use-n1-6-trn-service- widevote/

Omitoogun, W. \& Oduntan, T. (2006). Budgeting for the military sector in Africa: The processes and mechanisms of control. [online] Available at http://www.ssrnetwork.net/document library/detail/4257/Budgeting-forthemilitary-sector-in-africa- -processes-and-mechanisms-of-control-nigeria

Omopariola, O. (2002). Nigeria's financial management nightmare. Retrieved from http://www.nuc.edu.ng/nucsite/file/ILS\%202002/ILS-64.pdf

Onyiah, I., Ezeamama, N., Ugwu, J. \& Mgbodile, C. (2016). Nigerian budget implementation and control reforms: Tools for Macro economic growth. British Journal of Economics, Management \& Trade. 11(2), 1-13.

Opalana, T. (2018, August 31) 2019: Crisis looms as NASS asks FG to vire fund from N943.5bn Service Wide Vote Retrieved from: https://dailytimes.ng/2019-crisis-looms- nass-asks-fg-vire-fund-n943- 5bn-servicewide-vote/

Ovuakporie, E. (2013, December 23) Federal Government allegedly lavished N4.7 Trillion in 8 Years - Reps. Retrieved from: https://www.vanguardngr.com/2013/12/fg-allegedly-lavished-n4-7trn-8yrs-reps/

Premchand, A. (2007). Public budgeting and economic development: Evolution and practice of an idea. International Journal of Public Administration, 24(10), 1023-1039. https://doi.org/10.1081/PAD100105100

Renzio, P. \& Smith S. (2005). Linking policies and budgets: Implementing medium term expenditure frameworks in a PRSP context. [online] Retrieved from www.odi.org.uk

Theophilus, A. A., \& Perpetua, E. C. (2016). Budget padding: The Nigerian perspective. International Journal of Advanced Academic Research | Social \& Management Sciences, 2(12), 41-56.

Ugoh, S. \& Ukpere, W. (2009). Problems and prospects of budgeting and budget implementation in Local Government System in Nigeria. African Journal of Business Management, 3(12), 836-846. doi: 10.5897/AJBM09.301

Ujah, E. (2018, February 1) Akabueze explains rising service wide vote. Vanguard Newspaper. Retrieved from: https://www.vanguardngr.com/2018/02/akabueze-explains-rising-service-wide-vote/ 


\section{APPENDIX}

\section{TABLE 1: RESEARCH QUESTIONNAIRE}

To what extent do you agree with each of the following statements in sections A and B below? Please indicate your answer by ticking right $(\sqrt{ })$ against the response option of your choice.

\begin{tabular}{|c|c|c|c|c|c|c|}
\hline $\mathbf{S} / \mathbf{N}$ & $\begin{array}{l}\text { How significant is the relationship between } \\
\text { the respondents' perception of the use of } \\
\text { service wide vote for national development } \\
\text { and their perceptions of the level of national } \\
\text { development in Nigeria? }\end{array}$ & $\begin{array}{l}\text { Strongly } \\
\text { Disagree }\end{array}$ & Disagree & Undecided & Agree & $\begin{array}{l}\text { Strongly } \\
\text { Agree }\end{array}$ \\
\hline $\mathbf{A}$ & Use of Service Wide Vote (USWV) & & & & & \\
\hline 1 & $\begin{array}{l}\text { In my Organization, virement is approved } \\
\text { from the service wide vote }\end{array}$ & 1 & 2 & 3 & 4 & 5 \\
\hline 2 & $\begin{array}{l}\text { In my Organization, amount received as } \\
\text { service wide vote is properly accounted for. }\end{array}$ & 1 & 2 & 3 & 4 & 5 \\
\hline 3 & $\begin{array}{l}\text { The service wide vote collected by my } \\
\text { Organization does not exceed } 5 \text { percent of } \\
\text { its annual budget. }\end{array}$ & 5 & 4 & 3 & 2 & 1 \\
\hline 4 & $\begin{array}{l}\text { My Organization replenishes it service wide } \\
\text { vote as soon as it is exhausted. }\end{array}$ & 1 & 2 & 3 & 4 & 5 \\
\hline 5 & $\begin{array}{l}\text { My Organization uses the service wide vote } \\
\text { strongly for expenditure items that are not } \\
\text { found in the regular budget. }\end{array}$ & 1 & 2 & 3 & 4 & 5 \\
\hline 6 & $\begin{array}{l}\text { In my Organization, loans are granted from } \\
\text { the service wide vote. }\end{array}$ & 1 & 2 & 3 & 4 & 5 \\
\hline 7 & $\begin{array}{l}\text { My Organization does not spend from the } \\
\text { service wide vote without obtaining } \\
\text { approval from the legislature. }\end{array}$ & 1 & 2 & 3 & 4 & 5 \\
\hline 8 & $\begin{array}{l}\text { The use of service wide vote in my } \\
\text { Organization is regularly audited }\end{array}$ & 1 & 2 & 3 & 4 & 5 \\
\hline 9 & $\begin{array}{l}\text { No fraudulent use of service wide vote has } \\
\text { so far been reported against my } \\
\text { Organization. }\end{array}$ & 1 & 2 & 3 & 4 & 5 \\
\hline 10 & $\begin{array}{l}\text { My Organization uses the service wide vote } \\
\text { to take care of all its emergencies and } \\
\text { unforeseen expenditures. }\end{array}$ & 1 & 2 & 3 & 4 & 5 \\
\hline 11 & $\begin{array}{l}\text { The service wide vote has prevented my } \\
\text { Organization from borrowing excessively. }\end{array}$ & 5 & 4 & 3 & 2 & 1 \\
\hline
\end{tabular}

\begin{tabular}{|c|c|c|c|c|c|c|}
\hline B & National Development (NDEV) & $\begin{array}{l}\text { Strongly } \\
\text { Disagree }\end{array}$ & Disagree & Undecided & Agree & $\begin{array}{l}\text { Strongly } \\
\text { Agree }\end{array}$ \\
\hline 1 & $\begin{array}{l}\text { My community has enjoyed constant } \\
\text { electricity and water supply. }\end{array}$ & 1 & 2 & 3 & 4 & 5 \\
\hline 2 & $\begin{array}{l}\text { The National Social Investment Programme } \\
\text { (NSIP) has been implemented in my } \\
\text { community. }\end{array}$ & 1 & 2 & 3 & 4 & 5 \\
\hline 3 & $\begin{array}{l}\text { Improved health care services have been } \\
\text { attracted to my community. }\end{array}$ & 5 & 4 & 3 & 2 & 1 \\
\hline 4 & $\begin{array}{l}\text { Government have built new hospitals for } \\
\text { my community. }\end{array}$ & 1 & 2 & 3 & 4 & 5 \\
\hline 5 & $\begin{array}{l}\text { My community now enjoys a better road } \\
\text { network and improved transport services. }\end{array}$ & 1 & 2 & 3 & 4 & 5 \\
\hline 6 & $\begin{array}{l}\text { Crime rate and insurgencies in my } \\
\text { community have been drastically reduced. }\end{array}$ & 1 & 2 & 3 & 4 & 5 \\
\hline 7 & $\begin{array}{l}\text { My community has benefited from home } \\
\text { grown school feeding introduced by federal } \\
\text { government of Nigeria. }\end{array}$ & 1 & 2 & 3 & 4 & 5 \\
\hline
\end{tabular}




\begin{tabular}{|c|l|c|c|c|c|c|}
\hline B & National Development (NDEV) & $\begin{array}{l}\text { Strongly } \\
\text { Disagree }\end{array}$ & Disagree & Undecided & Agree & $\begin{array}{c}\text { Strongly } \\
\text { Agree }\end{array}$ \\
\hline 8 & $\begin{array}{l}\text { Government response to disaster situations } \\
\text { in my community has been very } \\
\text { encouraging. }\end{array}$ & 1 & 2 & 3 & 4 & 5 \\
\hline 9 & $\begin{array}{l}\text { Many abandoned projects in my } \\
\text { community have been duly implemented. }\end{array}$ & 1 & 2 & 3 & 4 & 5 \\
\hline 10 & $\begin{array}{l}\text { Farmers in my community have benefited } \\
\text { from government loans. }\end{array}$ & 1 & 2 & 3 & 4 & 5 \\
\hline 11 & $\begin{array}{l}\text { My community has benefited tremendously } \\
\text { from government programmes aimed at } \\
\text { improving the people's living standard. }\end{array}$ & 5 & 4 & 3 & 2 & 1 \\
\hline
\end{tabular}

TABLE 2: DISTRIBUTION OF RESPONDENTS BY MDAS MINISTRIES, DEPARTMENTS AND AGENCIES

\begin{tabular}{|l|c|c|}
\hline \multicolumn{1}{|c|}{ MINISTRIES, DEPARTMENTS AND AGENCIES } & $\begin{array}{c}\text { NUMBER OF } \\
\text { RESPONDENTS }\end{array}$ & $\begin{array}{c}\text { PERCENTAGE OF } \\
\text { RESPONDENTS (\%) }\end{array}$ \\
\hline Office of the Auditor-General for Cross River State & 12 & 35 \\
\hline Office of the Auditor-General for Local Government, CRS. & 8 & 24 \\
\hline Cross River State House of Assembly & 8 & 24 \\
\hline State Planning Commission, Cross River State & 6 & 18 \\
\hline Total Number of Respondents & $\mathbf{3 4}$ & $\mathbf{1 0 0}$ \\
\hline
\end{tabular}

TABLE 3: DISTRIBUTION OF 5-POINTS LIKERT SCALE RESPONSE SCORES AND TOTAL SCORES FOR USE OF SERVICE WIDE VOTE (USWV)

\begin{tabular}{|c|c|c|c|c|c|c|c|c|c|c|c|c|}
\hline ID Number & Item 1 & Item 2 & Item 3 & Item 4 & Item 5 & Item 6 & Item 7 & Item 8 & Item 9 & Item 10 & Item 11 & Total Scores \\
\hline 1 & 5 & 4 & 3 & 5 & 4 & 4 & 4 & 4 & 3 & 4 & 3 & 43 \\
\hline 2 & 4 & 4 & 4 & 4 & 4 & 5 & 5 & 4 & 5 & 4 & 5 & 48 \\
\hline 3 & 4 & 4 & 4 & 4 & 4 & 5 & 5 & 5 & 5 & 4 & 5 & 49 \\
\hline 4 & 4 & 4 & 4 & 4 & 5 & 5 & 4 & 4 & 5 & 4 & 5 & 48 \\
\hline 5 & 5 & 4 & 5 & 4 & 4 & 4 & 4 & 4 & 5 & 4 & 5 & 48 \\
\hline 6 & 5 & 4 & 5 & 4 & 4 & 4 & 4 & 4 & 4 & 4 & 5 & 47 \\
\hline 7 & 5 & 4 & 5 & 4 & 4 & 4 & 4 & 4 & 4 & 4 & 5 & 47 \\
\hline 8 & 4 & 4 & 4 & 4 & 4 & 4 & 5 & 5 & 4 & 5 & 5 & 48 \\
\hline 9 & 4 & 3 & 4 & 3 & 3 & 3 & 3 & 3 & 3 & 4 & 5 & 38 \\
\hline 10 & 5 & 4 & 4 & 4 & 4 & 4 & 4 & 4 & 4 & 4 & 4 & 45 \\
\hline 11 & 5 & 4 & 4 & 4 & 4 & 3 & 4 & 3 & 4 & 4 & 4 & 43 \\
\hline 12 & 5 & 5 & 5 & 5 & 5 & 5 & 5 & 5 & 5 & 5 & 4 & 54 \\
\hline 13 & 5 & 4 & 5 & 4 & 4 & 4 & 4 & 4 & 4 & 4 & 4 & 46 \\
\hline 14 & 5 & 4 & 5 & 4 & 4 & 4 & 3 & 4 & 4 & 4 & 4 & 45 \\
\hline 15 & 5 & 5 & 4 & 4 & 3 & 3 & 5 & 4 & 4 & 5 & 3 & 45 \\
\hline 16 & 5 & 4 & 4 & 3 & 3 & 4 & 4 & 4 & 4 & 5 & 5 & 45 \\
\hline 17 & 4 & 3 & 3 & 5 & 4 & 3 & 3 & 3 & 5 & 3 & 3 & 39 \\
\hline 18 & 5 & 4 & 4 & 4 & 5 & 3 & 3 & 5 & 4 & 4 & 4 & 45 \\
\hline 19 & 5 & 4 & 4 & 5 & 4 & 5 & 5 & 4 & 4 & 4 & 4 & 48 \\
\hline 20 & 4 & 3 & 3 & 4 & 4 & 4 & 3 & 3 & 4 & 5 & 4 & 41 \\
\hline 21 & 5 & 3 & 4 & 3 & 3 & 5 & 5 & 3 & 5 & 3 & 5 & 44 \\
\hline 22 & 5 & 3 & 3 & 3 & 3 & 5 & 5 & 5 & 5 & 3 & 5 & 45 \\
\hline 23 & 5 & 3 & 4 & 3 & 5 & 5 & 3 & 3 & 5 & 4 & 5 & 45 \\
\hline 24 & 5 & 4 & 3 & 4 & 4 & 4 & 4 & 4 & 3 & 3 & 4 & 42 \\
\hline 25 & 5 & 4 & 3 & 4 & 4 & 4 & 4 & 4 & 4 & 4 & 3 & 43 \\
\hline 26 & 5 & 4 & 5 & 4 & 4 & 4 & 4 & 4 & 4 & 4 & 4 & 46 \\
\hline 27 & 5 & 4 & 4 & 4 & 4 & 5 & 4 & 5 & 4 & 4 & 5 & 48 \\
\hline 28 & 5 & 4 & 4 & 4 & 4 & 4 & 4 & 4 & 4 & 4 & 5 & 46 \\
\hline 29 & 5 & 3 & 4 & 3 & 3 & 3 & 3 & 3 & 3 & 3 & 3 & 36 \\
\hline 30 & 5 & 4 & 4 & 3 & 3 & 4 & 4 & 5 & 4 & 5 & 5 & 46 \\
\hline 31 & 5 & 4 & 5 & 4 & 4 & 5 & 5 & 4 & 5 & 5 & 4 & 50 \\
\hline 32 & 4 & 3 & 4 & 3 & 5 & 4 & 3 & 5 & 4 & 4 & 4 & 43 \\
\hline 33 & 4 & 3 & 4 & 5 & 3 & 5 & 5 & 3 & 3 & 4 & 4 & 43 \\
\hline 34 & 5 & 5 & 5 & 4 & 4 & 4 & 5 & 5 & 5 & 4 & 4 & 50 \\
\hline
\end{tabular}


ISSN 2222-1697 (Paper) ISSN 2222-2847 (Online)

TABLE 4: DISTRIBUTION OF 5-POINTS LIKERT SCALE RESPONSE SCORES AND TOTAL SCORES FOR NATIONAL DEVELOPMENT (NDEV)

\begin{tabular}{|c|c|c|c|c|c|c|c|c|c|c|c|c|}
\hline ID Number & Item 1 & Item 2 & Item 3 & Item 4 & Item 5 & Item 6 & Item 7 & Item 8 & Item 9 & Item 10 & Item 11 & Total Scores \\
\hline 1 & 2 & 2 & 1 & 3 & 2 & 2 & 2 & 2 & 1 & 1 & 1 & 19 \\
\hline 2 & 1 & 2 & 2 & 2 & 2 & 3 & 3 & 2 & 3 & 2 & 3 & 25 \\
\hline 3 & 1 & 2 & 2 & 2 & 2 & 3 & 3 & 3 & 3 & 2 & 3 & 26 \\
\hline 5 & 1 & 1 & 2 & 1 & 1 & 1 & 1 & 1 & 2 & 2 & 2 & 15 \\
\hline 6 & 1 & 1 & 2 & 1 & 1 & 1 & 1 & 1 & 1 & 1 & 2 & 13 \\
\hline 7 & 1 & 1 & 2 & 1 & 1 & 1 & 1 & 1 & 1 & 1 & 2 & 13 \\
\hline 10 & 2 & 2 & 2 & 2 & 2 & 2 & 2 & 2 & 2 & 2 & 2 & 22 \\
\hline 11 & 2 & 2 & 2 & 2 & 2 & 1 & 2 & 1 & 2 & 2 & 2 & 20 \\
\hline 12 & 1 & 2 & 2 & 2 & 2 & 2 & 2 & 2 & 2 & 2 & 1 & 20 \\
\hline 13 & 2 & 2 & 3 & 2 & 2 & 2 & 2 & 2 & 2 & 2 & 2 & 23 \\
\hline 14 & 2 & 2 & 3 & 2 & 2 & 2 & 1 & 2 & 2 & 2 & 2 & 22 \\
\hline 15 & 2 & 3 & 2 & 2 & 1 & 1 & 3 & 2 & 2 & 3 & 1 & 22 \\
\hline 20 & 1 & 1 & 1 & 2 & 2 & 2 & 1 & 1 & 2 & 3 & 2 & 18 \\
\hline 21 & 2 & 1 & 2 & 1 & 1 & 3 & 3 & 1 & 3 & 1 & 3 & 21 \\
\hline 22 & 2 & 1 & 1 & 1 & 1 & 3 & 3 & 3 & 3 & 1 & 3 & 22 \\
\hline 23 & 2 & 1 & 2 & 1 & 3 & 3 & 1 & 1 & 3 & 2 & 3 & 22 \\
\hline 24 & 2 & 2 & 1 & 2 & 2 & 2 & 2 & 2 & 1 & 1 & 2 & 19 \\
\hline 25 & 2 & 2 & 1 & 2 & 2 & 2 & 2 & 2 & 2 & 2 & 1 & 20 \\
\hline 26 & 2 & 1 & 2 & 1 & 1 & 1 & 1 & 1 & 1 & 1 & 1 & 13 \\
\hline 27 & 1 & 1 & 1 & 1 & 1 & 2 & 1 & 2 & 1 & 1 & 2 & 14 \\
\hline 28 & 2 & 1 & 1 & 1 & 1 & 1 & 1 & 1 & 1 & 1 & 2 & 13 \\
\hline 29 & 1 & 1 & 3 & 1 & 1 & 1 & 1 & 1 & 1 & 1 & 1 & 13 \\
\hline 30 & 2 & 2 & 2 & 1 & 1 & 2 & 2 & 3 & 2 & 3 & 3 & 23 \\
\hline
\end{tabular}


TABLE 5: Results of Testing the Reliability of the Primary Data Collected for Use of Service Wide Vote Using Cronbach's Alpha Technique (The acceptable Reliability Coefficient of 0.70 was obtained for the data. Please see Reliability Statistics table as shown below)

GET

FILE='C: USers\Lizay DoeumentshLikert scale data for use of service wide vote.sav'. DATASET NAME DataSEt 1 WINDOU=FRONT. RELIAEILITY

VhRI hELES=Item 1 Item 2 Item 3 Item 4 Item 5 Item 6 Item 7 Item 8 Item 9 Item 10 Item 11

/SCALE!'ALL VARIABLES') 'ं ALL

$\angle$ MODEL $=$ LLFHÄ

/STATISTICS=DESCRIPTIVE SCALE CORR

$/$ SUMMдRY=TOTムL .

\section{Reliability}

[Dataset1] C:YJsersłLizay DocumentshLikert scale date for use of service wide vote.sav

Scale: ALL

\begin{tabular}{|ll|r|r|}
\multicolumn{4}{c}{ Case Processing Summary } \\
\hline & \multicolumn{1}{|c|}{$N$} & \multicolumn{1}{c|}{$\%$} \\
\hline Cases & Valid & 34 & 100.0 \\
& Excluded & 0 & .0 \\
& Total & 34 & 100.0 \\
\hline
\end{tabular}

a. Listwise deletian based on all variables in the procedure.

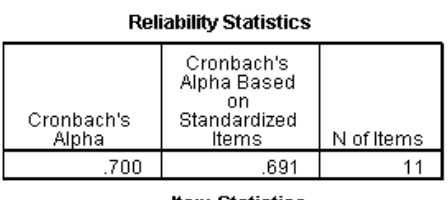

Item Statistics

\begin{tabular}{|l|r|r|r|}
\hline & \multicolumn{1}{|c|}{ Mean } & Std. Deviation & \multicolumn{1}{|c|}{ N } \\
\hline Item_1 & 4.74 & .448 & 34 \\
Item_2 & 3.82 & .576 & 34 \\
Item_3 & 4.09 & .668 & 34 \\
Item_4 & 3.91 & .621 & 34 \\
Item_5 & 3.91 & .621 & 34 \\
Item_6 & 4.15 & .702 & 34 \\
Item_7 & 4.09 & .753 & 34 \\
Item_8 & 4.03 & .717 & 34 \\
Item_9 & 4.18 & .673 & 34 \\
Item_10 & 4.06 & .600 & 34 \\
Item_11 & 4.29 & .719 & 34 \\
\hline
\end{tabular}

Inter-ltem Correlation hiatrix

\begin{tabular}{|c|c|c|c|c|c|c|c|c|c|c|c|}
\hline & Item 1 & Item 2 & Item_3 & Item 4 & Item_5 & Item_ 6 & Item 7 & Item $\mathrm{g}$ & Item $\mathrm{g}$ & Item_10 & Item_11 \\
\hline Item_1 & 1.000 & .401 & .283 & -.087 & -.087 & -.065 & .071 & .119 & -.041 & -.053 & -.127 \\
\hline Item_2 & 401 & 1.000 & .435 & .379 & .209 & -.009 & .456 & .527 & .161 & 469 & -.090 \\
\hline Item_3 & .283 & .435 & 1.000 & .019 & .165 & .101 & .165 & .184 & .234 & 209 & .260 \\
\hline Item_4 & -.087 & .379 & .019 & 1.000 & .293 & 100 & .276 & .006 & -.034 & .096 & -.415 \\
\hline Item_5 & -.087 & .209 & .165 & .293 & 1.000 & .170 & -.242 & .278 & .328 & .096 & -.008 \\
\hline Item_6 & -.065 & -.009 & .101 & 100 & .170 & 1.000 & .548 & .232 & .457 & .051 & .452 \\
\hline Item_7 & .071 & .456 & 165 & .276 & -.242 & .540 & 1.000 & .332 & .327 & .189 & 174 \\
\hline Item_8 & .119 & .527 & .194 & .006 & .270 & .232 & .332 & 1.000 & .240 & .270 & .218 \\
\hline Item_g & -.041 & .161 & .234 & -.034 & .328 & .457 & .327 & 240 & 1.000 & .049 & .328 \\
\hline Item_10 & -.053 & .469 & .289 & .096 & .096 & .051 & .189 & .278 & .049 & 1.000 & .099 \\
\hline Item_11 & -.127 & -.090 & .260 & -.415 & -.008 & .452 & .174 & .219 & .320 & .099 & 1.000 \\
\hline
\end{tabular}

Item-Total Statistics

\begin{tabular}{|c|c|c|c|c|c|}
\hline & $\begin{array}{l}\text { Scale Mean if } \\
\text { ltem Deleted }\end{array}$ & $\begin{array}{c}\text { Scale } \\
\text { variance if } \\
\text { Item Leleted }\end{array}$ & $\begin{array}{l}\text { Corrected } \\
\text { Item-Total } \\
\text { Correlation }\end{array}$ & $\begin{array}{c}\text { Squared } \\
\text { Multiple } \\
\text { correlation } \\
\end{array}$ & $\begin{array}{l}\text { Cronbach's } \\
\text { Alpha if Item } \\
\text { Deleteded }\end{array}$ \\
\hline Item_1 & 40.53 & 12.378 & .072 & 470 & .711 \\
\hline Item_2 & 41.44 & 10.315 & .584 & .810 & 645 \\
\hline Item_3 & 41.18 & 10.574 & 411 & .357 & .669 \\
\hline Item_4 & 41.35 & 11.932 & .114 & .592 & .714 \\
\hline Item_5 & 41.35 & 11.447 & 232 & 667 & 697 \\
\hline Item_6 & 41.12 & 10.289 & 450 & .700 & .662 \\
\hline Item_? & 41.18 & 9.968 & 477 & .790 & .655 \\
\hline Item_8 & 41.24 & 10.064 & 490 & .480 & .654 \\
\hline Item_g & 41.09 & 10.447 & 438 & 425 & .664 \\
\hline Item_10 & 41.21 & 11.199 & 311 & 371 & 685 \\
\hline Item_11 & 40.97 & 11.302 & 204 & .524 & .704 \\
\hline
\end{tabular}

Scale Statistics 
TABLE 6: Results of Testing the Reliability of the Primary Data Collected for National Development Using Cronbach's Alpha Technique (The acceptable Reliability Coefficient of 0.76 was obtained for the data. Please see Reliability Statistics table as shown below)

GET

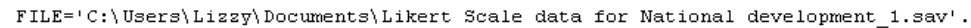
DATHSET NAME DataSET2 TI INDOTJ=FFONT.

DATuSET HCTIVHTE Dataset1.

DATHSET CLOSE Dataset?.

GET

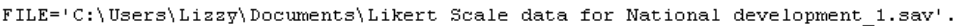

DATASET NBME DataSet3 WINDOW=FRONT.

RELIMEILITY

VinRüBLES=Item_1 Item_2 Item_3 Item_4 Item_5 Item_6 Item_7 Itern_8 Item_9 Item_10 Item_11

/SCALE['ALL VARIMBLES' $]$ ALI

/ MODEL $=$ SLFHA

/STATISTICS=DESCRIFTIVE SCALE CORR

/STMMART=TOTAL .

\section{Reliability}

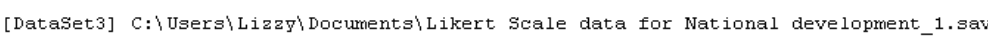

\section{Scale: ALL}

\begin{tabular}{|ll|r|r|}
\multicolumn{4}{c|}{ Case Processing Summary } \\
\hline & & \multicolumn{1}{c|}{ N } & \multicolumn{1}{c|}{$\%$} \\
\hline Cases & Valid & 34 & 100.0 \\
& Excluded & 0 & .0 \\
& Total & 34 & 100.0 \\
\hline
\end{tabular}

a. Listwise deletion based on all wariables in the procedure

Reliability Statistics

\begin{tabular}{|c|c|c|c|c|}
\hline $\begin{array}{c}\text { Cronbach's } \\
\text { Alphá }\end{array}$ & \multicolumn{2}{|c|}{$\begin{array}{l}\text { Cronbach's } \\
\text { Alpha Based } \\
\text { on } \\
\text { standardized } \\
\text { ltems }\end{array}$} & \multicolumn{2}{|c|}{ Nof Items } \\
\hline & 66 & 744 & & 11 \\
\hline \multicolumn{5}{|c|}{ Item Statistics } \\
\hline & Mean & Std Dewia & ation & N \\
\hline Item_1 & 1.50 & & .508 & 34 \\
\hline Item_2 & 1.56 & & .561 & 34 \\
\hline Item_3 & 1.88 & & .591 & 34 \\
\hline Item_4 & 1.65 & & 691 & 34 \\
\hline Item_ 5 & 1.65 & & 691 & 34 \\
\hline Item_E & 1.88 & & .769 & 34 \\
\hline Item_? & 1.82 & & .797 & 34 \\
\hline Item_8 & 1.76 & & .741 & 34 \\
\hline Item_g & 1.97 & & .758 & 34 \\
\hline Item_10 & 1.76 & & .699 & 34 \\
\hline Item_11 & 2.00 & & .739 & 34 \\
\hline
\end{tabular}

Inter-Item Correlation Matrix

\begin{tabular}{|c|c|c|c|c|c|c|c|c|c|c|c|}
\hline & Item_1 & Item_2 & Item_3 & |tem_4 & Item_5 & Item_E & Item_7 & Item_g & Item_g & Item_10 & Item_11 \\
\hline Item_1 & 1.000 & 373 & -.101 & .086 & .086 & 078 & 150 & 161 & -.039 & .085 & .081 \\
\hline Item_2 & 373 & 1.000 & .113 & 446 & 290 & .087 & 499 & 545 & 182 & 500 & .000 \\
\hline Item_3 & -101 & 113 & 1.000 & -179 & -.031 & -098 & -.045 & -.065 & -.008 & 151 & .069 \\
\hline Item_4 & .086 & 446 & -.179 & 1.000 & 429 & 261 & .379 & 129 & .037 & 199 & -.179 \\
\hline Item_5 & .086 & 290 & -.031 & .429 & 1.000 & 318 & -.062 & 365 & 327 & 262 & .179 \\
\hline Item_8 & .078 & .087 & -.098 & .281 & 318 & 1.000 & .608 & .322 & 461 & .229 & .597 \\
\hline Item_? & .150 & .499 & -.045 & .379 & -.062 & 608 & 1.000 & 390 & 393 & .304 & .309 \\
\hline Item_8 & 181 & 545 & -.065 & .129 & 365 & 322 & .390 & 1.000 & 257 & .358 & .332 \\
\hline Item_9 & -.039 & 182 & -.008 & 037 & 327 & 461 & .393 & 257 & 1.000 & .272 & 325 \\
\hline Item_10 & .085 & 500 & .151 & 199 & 262 & 229 & 304 & 358 & 272 & 1.000 & .294 \\
\hline Item_11 & 081 & 000 & .069 & .178 & 178 & .587 & 309 & 332 & 325 & 294 & 1.000 \\
\hline
\end{tabular}

Item-Total Statistics

\begin{tabular}{|c|c|c|c|c|c|}
\hline & $\begin{array}{l}\text { Scale Wean if } \\
\text { Item Deleted }\end{array}$ & $\begin{array}{c}\text { Scale } \\
\text { Variance if } \\
\text { ltem Deleted }\end{array}$ & $\begin{array}{l}\text { Coprected } \\
\text { lem-Tutal } \\
\text { Correlation }\end{array}$ & $\begin{array}{c}\text { Squared } \\
\text { multitiple } \\
\text { Correlation }\end{array}$ & $\begin{array}{l}\text { Cronbach's } \\
\text { Alpha if them } \\
\text { Deleted }\end{array}$ \\
\hline Item_1 & 17.94 & 15.875 & 165 & .256 & .761 \\
\hline Item_2 & 17.88 & 14.107 & .564 & .755 & .722 \\
\hline Item_3 & 17.56 & 16.618 & -.035 & .187 & .783 \\
\hline Item_4 & 17.79 & 14.775 & 291 & .654 & .751 \\
\hline Item_5 & 17.79 & 14.229 & 401 & .709 & .738 \\
\hline Item_E & 17.56 & 12.981 & 582 & .733 & .711 \\
\hline Item_? & 17.62 & 12.910 & 569 & .809 & .713 \\
\hline Item_8 & 17.68 & 13.377 & 530 & .531 & .720 \\
\hline Item_ 9 & 17.47 & 13.772 & 436 & .442 & .733 \\
\hline Item_10 & 17.68 & 13.741 & 496 & .373 & .725 \\
\hline Item_11 & 17.44 & 14.072 & 394 & .544 & .739 \\
\hline
\end{tabular}

Scale Statistics 
TABLE 7: DISTRIBUTION OF TOTAL SCORES FOR USE OF SERVICE WIDE VOTE (USWV) AND NATIONAL DEVELOPMENT (NDEV)

\begin{tabular}{|c|c|c|}
\hline PARTICIPANTS' ID & USWV & NDEV \\
\hline 1 & 43 & 19 \\
\hline 2 & 48 & 25 \\
\hline 3 & 49 & 26 \\
\hline 4 & 48 & 25 \\
\hline 5 & 48 & 15 \\
\hline 6 & 47 & 13 \\
\hline 7 & 47 & 13 \\
\hline 8 & 48 & 25 \\
\hline 9 & 38 & 14 \\
\hline 10 & 45 & 22 \\
\hline 11 & 43 & 20 \\
\hline 12 & 54 & 20 \\
\hline 13 & 46 & 23 \\
\hline 14 & 45 & 22 \\
\hline 15 & 45 & 22 \\
\hline 16 & 45 & 22 \\
\hline 17 & 39 & 16 \\
\hline 18 & 45 & 22 \\
\hline 19 & 48 & 25 \\
\hline 20 & 41 & 18 \\
\hline 21 & 44 & 21 \\
\hline 22 & 45 & 22 \\
\hline 23 & 45 & 22 \\
\hline 24 & 42 & 19 \\
\hline 25 & 43 & 20 \\
\hline 26 & 46 & 13 \\
\hline 27 & 48 & 14 \\
\hline 28 & 46 & 13 \\
\hline 29 & 36 & 13 \\
\hline 30 & 46 & 23 \\
\hline 31 & 50 & 17 \\
\hline 32 & 43 & 20 \\
\hline 33 & 43 & 20 \\
\hline 34 & 50 & 17 \\
\hline
\end{tabular}


TABLE 8: The results of simple regression analysis of the USWV and NDEV data from table 7

\section{Regression}

[DataSet4] C:UsersłLizag Doeuments Continous Data for Use of service tide vote and national development.sav Descriptime Statistics

\begin{tabular}{|l|r|r|r|}
\hline & Mean & Std. Deviation & \multicolumn{1}{|c|}{$N$} \\
\hline National Dewelopment & 19.44 & 4.099 & 34 \\
$\begin{array}{l}\text { Use of the Serwice Wide } \\
\text { vote }\end{array}$ & 45.26 & 3.579 & 34 \\
\hline
\end{tabular}

Correlations

\begin{tabular}{|c|c|c|c|}
\hline & & $\begin{array}{c}\text { National } \\
\text { Development }\end{array}$ & $\begin{array}{c}\text { Use of the } \\
\text { Service vilide } \\
\text { Vote }\end{array}$ \\
\hline \multirow[t]{2}{*}{ Pearson Correlation } & National Development & 1.000 & 271 \\
\hline & $\begin{array}{l}\text { Uee of the Service Mide } \\
\text { vote }\end{array}$ & .271 & 1.000 \\
\hline \multirow[t]{2}{*}{ Sig. (1-tailed) } & National Dewelopment & & \multirow[t]{2}{*}{.061} \\
\hline & $\begin{array}{l}\text { Uee of the Serwice mide } \\
\text { Vote }\end{array}$ & .061 & \\
\hline \multirow[t]{2}{*}{$N$} & National Dewelopment & 34 & 34 \\
\hline & $\begin{array}{l}\text { Use of the Service Wide } \\
\text { Vote }\end{array}$ & 34 & 34 \\
\hline
\end{tabular}

Variables Entered/Remowed

\begin{tabular}{|l|l|l|l|}
\hline Wode & $\begin{array}{c}\text { Variables } \\
\text { Entered }\end{array}$ & \multicolumn{1}{|c|}{$\begin{array}{c}\text { Variables } \\
\text { Remowed }\end{array}$} & Wethod \\
\hline 1 & $\begin{array}{l}\text { Use of the } \\
\text { Service Wide } \\
\text { Vote }\end{array}$ & & Enter \\
\hline
\end{tabular}

a. All requested variables entered.

b. Dependent Variable: National Development

hodel Summary

\begin{tabular}{|c|c|c|c|c|}
\hline Mode & $\mathrm{R}$ & R Square & $\begin{array}{c}\text { Adjusted R } \\
\text { Square }\end{array}$ & $\begin{array}{l}\text { Std. Error of } \\
\text { the Estimate }\end{array}$ \\
\hline 1 & .2711 & .073 & .044 & 4.000 \\
\hline
\end{tabular}

a. Predictors (Constant), Use of the Service Wide vote

ANOWA ${ }^{\text {b }}$

\begin{tabular}{|rl|r|r|r|r|r|}
\hline Madel & & \multicolumn{1}{|c|}{$\begin{array}{c}\text { Sum of } \\
\text { Squares }\end{array}$} & \multicolumn{1}{c|}{ df } & Mean Square & F & Sig. \\
\hline 1 & Regression & 40.625 & 1 & 40.625 & 2.530 & .122 \\
& Residual & 513.758 & 32 & 16.055 & & \\
& Total & 554.382 & 33 & & & \\
\hline
\end{tabular}

a. Fredictors: (Constant), Use of the Service Wide Vote

b. Dependent Yariable: National Development

Coefficients

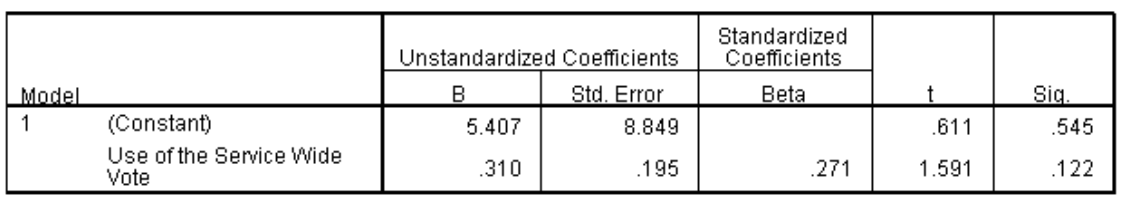

a. Dependent Yariable: National Development 
Test of the Linear Relationship between Use of Service Wide Vote and National Development prior to the application of simple linear regression analysis.

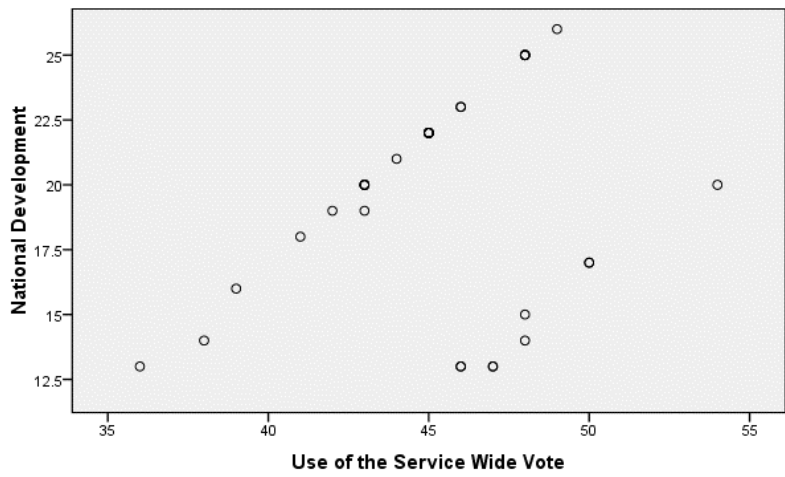

Figure 1

Graph

A Test verifying whether the data collected in respect of the use of service wide vote were normally distributed

Result: The bell-shape nature of the curve indicates that the Service Wide Vote Data are normally distributed

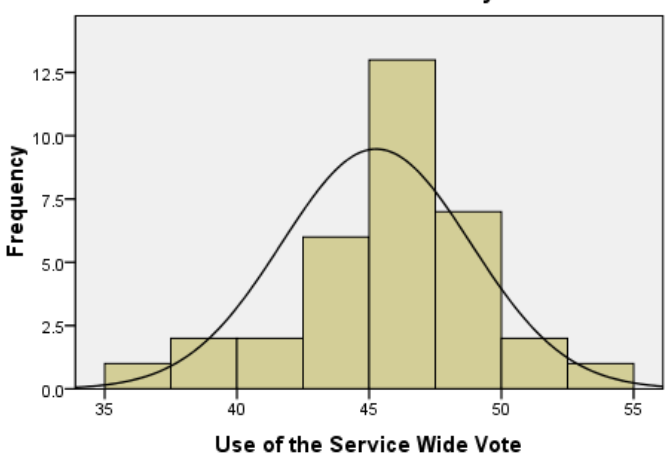

Mean $=45.26$
Std. Dev. $=3.579$
$N=34$

Figure 2

Graph

A Test verifying whether the data collected in respect of national development were normally distributed

Result: The bell-shape nature of the curve indicates that national development Data are normally distributed

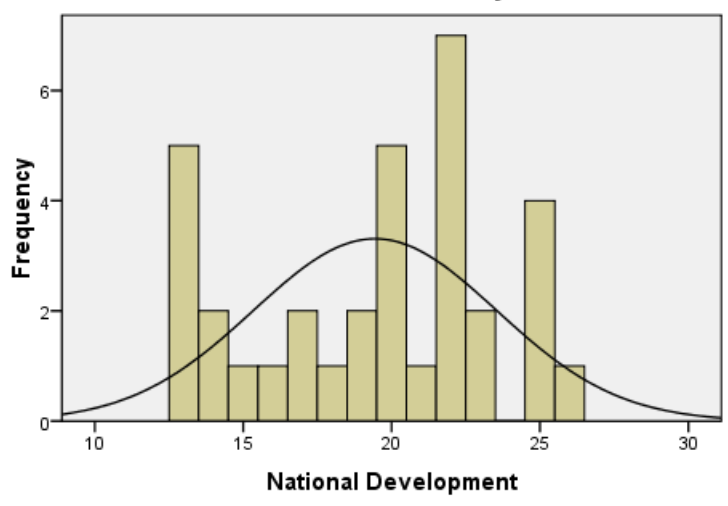

Mean $=19.44$
Stc. Dev. $=4.099$
$N=34$

Figure 3 